\title{
Pain and Health-Related Quality of Life After Oral Soft Tissue Surgical Intervention: The Advantages of the Nd:YAG Laser
}

\author{
Ilaria Giovannacci, Paolo Vescovi, Giovanni Mergoni, Carlo Fornaini, Mauro Bonanini, \\ Marco Meleti
}

Department of Biomedical, Biotechnological and Translational Sciences - Center of Oral Laser Surgery and Oral Medicine, Dental School, University of Parma, Italy.

Correspondinge-mail to: marco.meleti@unipr.it

\begin{abstract}
The new technology such as the neodymium-doped yttrium aluminum garnet (Nd:YAG) laser has been used for oral soft tissue surgery. Previous study shown that laser surgery resulted in lower morbidity and complication rates. Objective: This study aims to evaluate the differences in the post-operative course associated to the use of Nd:YAG laser and to cold blade after oral soft tissue surgery. Methods: One-hundred and eighteen comparable surgical interventions were evaluated. Group 1 (G1) included 77 interventions performed with Nd:YAG laser; group 2 (G2) 41 with cold blade. Acute post-operative pain was evaluated with visual analogue scale (VAS), numeric rating scale (NRS) and verbal rating scale-6 (VRS-6) on the same day of surgery, and at 1, 3 and 7 days after surgery.The HRQoL was evaluated on day 7 using a $0-45$ score range questionnaire. Data were analyzed using the software STATA 12 (StataCorp LP, College Station, Texas, USA). Results: No statistically significant differences could be highlighted in VAS and NRS scores. The VRS-6 scores resulted statistically significant at days 1 and 3. At day 1 , $47.14 \%$ of patients in G1 and $13.16 \%$ in G2 had no pain; at day 3, 62.86\% in G1 and $21.05 \%$ in G2 had no pain. The HRQoL in G1 was statistically higher than G2. Conclusion: The better HRQoL and the lower post-operative pain observed in laser-treated patients may be associated to the possible bio-modulating effect of the laser.
\end{abstract}

\begin{abstract}
ABSTRAK
Nyeri dan kualitas hidup terkait kesehatan setelah intervensi bedah jaringan lunak mulut: keuntungan penggunaan laser Nd:YAG. Teknologi laser neodymium-doped yttrium aluminum garnet (Nd:YAG) telah banyak digunakan untuk bedah jaringan lunak mulut. Penelitian terdahulu memperlihatkan bahwa bedah laser menurunkan angka morbiditas dan komplikasi. Tujuan: Penelitian ini bertujuan membandingkan penggunaan laser Nd:YAG dan pisau bedah untuk tatalaksana bedah lesi jaringan lunak mulut. Metode: Studi ini memeriksa 118 lesi yang dilakukan bedah. Grup 1 (G1) terdiri dari 77 kasus yang ditatalaksana dengan laser Nd:YAG; Grup 2 (G2) terdiri dari 41 kasus yang ditatalaksana bedah dengan pisau bedah. Nyeri akut paska operasi dievaluasi dengan visual analogue scale (VAS), numeric rating scale (NRS) dan verbal rating scale-6 (VRS-6) pada hari operasi dan 1, 3 dan 7 hari setelah operasi. HRQoL dievaluasi pada hari ke-10 menggunakan kuesioner dengan skor 0-45. Data dianalisis dengan STATA 12 (StataCorp LP, College Station, Texas, USA). Hasil: Tidak ada perbedaan bermakna antara skor VAS dan NRS pada kedua grup. Namun, terdapar perbedaan bermakna pada skor nyeri dengan VRS6 di hari ke-1 (47,14\% vs 13,16\%) dan hari ke-3 (62,86\% vs 21,05\%) kedua grup. Penelitian ini memperlihatkan bahwa HRQoL pada G1 lebih baik daripada G2. Simpulan: HRQoL yang lebih baik dan nyeri paska operasi yang lebih rendah terlihat pada pasien yang dilakukan bedah laser Nd:YAG. Hasil ini kemungkinan berkaitan dengan efek bio-modulasi dari laser.
\end{abstract}

Key words: discomfort, Nd:YAG laser, oral surgery, post-operative pain, quality of life 


\section{INTRODUCTION}

Oral soft tissue surgery can be performed through the use of new technologies such as the neodymium-doped yttrium aluminum garnet (Nd:YAG) laser. The $\mathrm{Nd}: \mathrm{YAG}$ laser generates light in the near infrared region of the spectrum at $1064 \mathrm{~nm}$. This wavelength is well absorbed by melanin and haemoglobin and this feature induces the haemostatic effect. Due to its poor absorption in water, the laser penetrates deeply into tissues, up to a depth of 4-5 mm. ${ }^{1}$ Laser surgery is associated with low morbidity and intraoperative and postoperative complication rates. ${ }^{2-4}$ Several reports highlighted that the positive effects of $\mathrm{Nd}$ :YAG laser are possibly related to its anti-bacterial, anti-inflammatory, analgesic and bio-stimulating properties. ${ }^{2-4}$ It is worth mentioning that comparative clinical studies between Nd:YAG and traditional surgical instruments are still scarce..$^{5-8}$

The aim of the present study is to evaluate and compare the possible post-operative advantages achieved with $\mathrm{Nd}$ :YAG laser taking into account, as control group, cases treated through conventional surgery (cold blade).

\section{METHODS}

One hundred and eighteen surgical interventions on oral soft tissues were performed on 118 patients (81 females, 37 males, mean age 58 years, ranging from 10 to 85 years) at the Center of Oral Laser Surgery and Oral Pathology of Parma, Italy, between December 2011 to August 2013. Interventions included incisional and excisional biopsies. All the surgical procedures were performed by the same operator. All specimens measured less than $3 \mathrm{~cm}$ in the larger size. Histopathological diagnosis included various mucosal conditions such as fibromas and fibropapillomas, epulides, mucoceles and potentially malignant disorders (e.g. lichen planus, leukoplakia). Surgical interventions were sub-classified according to the instrument used for excision: group 1 (G1) - Nd:YAG laser (output power: $3.5 \mathrm{~W}$; frequency: $60 \mathrm{~Hz}$; fiber diameter: $320 \mu \mathrm{m}$; power density 488,281 W/cm2); group 2 (G2) - Bard-Parker $n^{\circ} 15$ c scalpel blade: 41 cases.

Acute post-operative pain was evaluated with three different pain scales: the visual analogue scale (VAS), the numeric rating scale (NRS) and the verbal rating scale-6 (VRS-6). ${ }^{9}$ Each patient filled in a questionnaire the same day of surgery (day 0 ), and at 1,3 and 7 days after surgery (Figure 1).

In order to evaluate the impact of the intervention on the health-related quality of life (HRQoL) a modified version of the questionnaire proposed by Omer Waleed Majid was adopted..$^{10}$ The questionnaire was translated into Italian. Questions investigate different items such

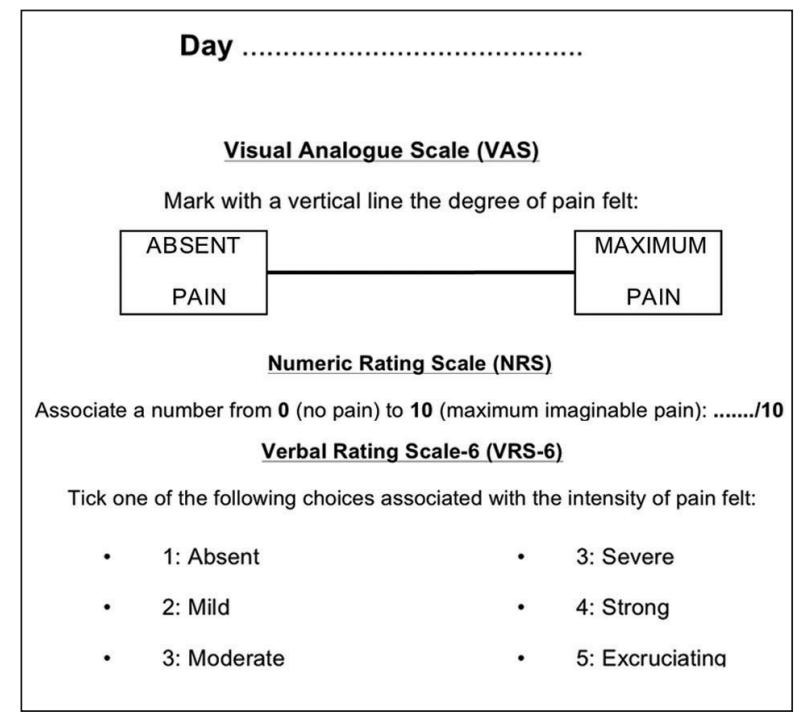

Figure 1. Questionnaire used for the evaluation of postoperative pain

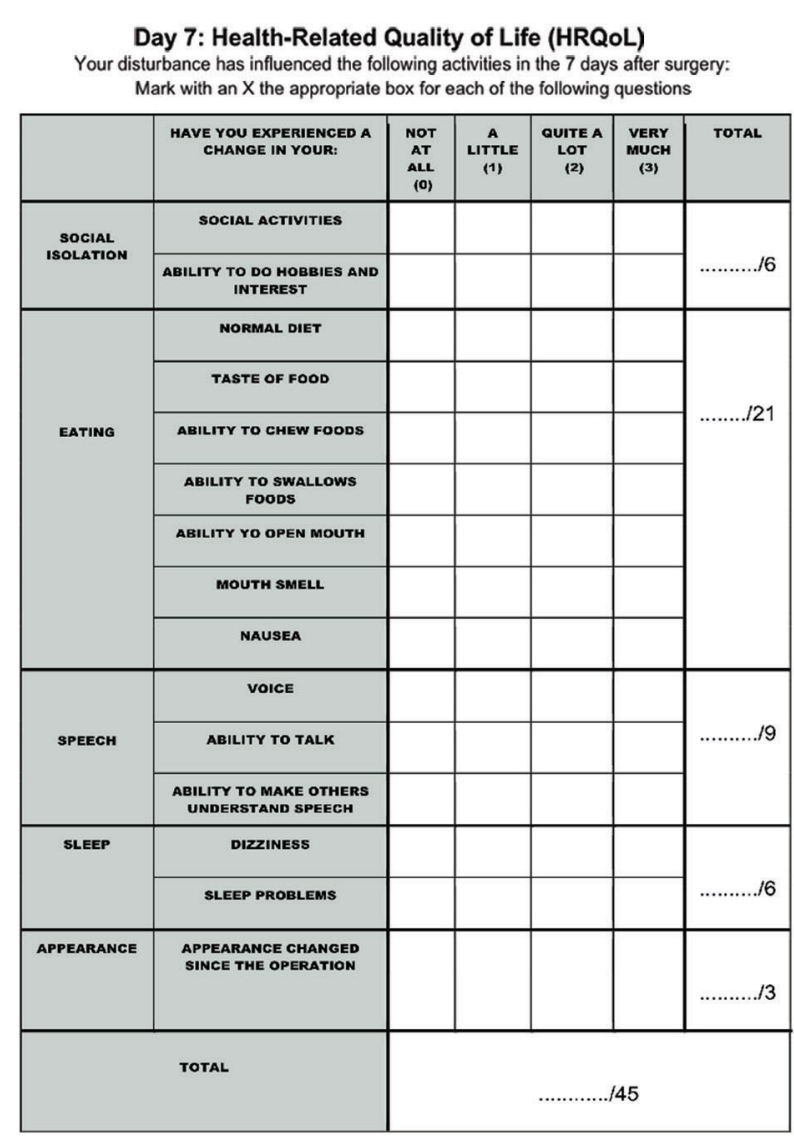

Figure 2. Questionnaire used for the evaluation of healthrelated quality of life

as social isolation, working isolation, eating ability and diet variations, speaking ability, sleep impairment and physical appearance (Figure 2). Compared to the original Majid's version the section "nausea" was added. Each item included several questions with a possible answer rated on a 4 -point scale $(0=$ never; 
$4=$ very much). Total score for each item could range from 0 to 45 . Patients were instructed to answer the questionnaire at day 7 after surgery as in Majid study. ${ }^{10}$ At day 7, painkillers taken and their dosage were recorded.

Data were analysed using the software STATA 12 (StataCorp LP, College Station, Texas, USA). The continuous variables are indicated as average \pm standard deviation; the numeric and ordinal categorical variables are indicated as percentage. The comparison of VAS and NRS scores recorded was performed with one-way repeated-measures ANOVA. The dichotomous categorical variables were analysed with Pearson chisquare test or, when indicated, with Fischer's exact test. These statistical test were used with contingency tables $2 \times 2$ (e.g. relation between VRS-6 score and days after surgery or relation between VRS-6 score and technology used).

The evaluation of HRQoL scores was performed with nonparametric Kruskal-Wallis test. Mann-Whitney $\mathrm{U}$ test was used for relative post-hoc analysis with Bonferroni correction for multiple comparisons. The probability to have a significant type alpha error was considered less than $5 \%$. Power of samples was tested before the statistical analysis using the ANOVA. Each test sample related to all variables (VAS, NRS, VRS-6, HRQoL) resulted significative $(p<0.0001)$.

\section{RESULTS}

The VAS scores in the totality of patients in G1 and G2 resulted statistically significant (ANOVA, $p<0.0001$ ). Then, in the post-hoc evaluation the comparison between the groups in every day was performed. The comparison between G1 and G2 did not result statistically significant at day $1(\mathrm{G} 1=1,33 \pm 2,30 ; \mathrm{G} 2=$ $2.13 \pm 2.04 ; p=0.0814), 3(\mathrm{G} 1=1.03 \pm 2.25 ; \mathrm{G} 2=1.44 \pm 1.52$; $p=0.1493)$ and $7(\mathrm{G} 1=0.92 \pm 2.32 ; \mathrm{G} 2=0.88 \pm 1.15$; $p=0.2966)$. A trend toward significance at day 0 ( $p=0,0597)$ was evident, with a mean VAS scores lower in G1 $(1.79 \pm 2.40)$ than G2 $(2.59 \pm 1.86)$.

The NRS scores in the totality of patients in G1 and G2 resulted statistically significant (ANOVA, $p<0.0001$ ). In the post hoc analysis all the comparisons between the groups were not statistically significant in any days. However, mean VAS and NRS scores result consistently lower in G1 than G2 (Figures 3 and 4). With regard to the VRS-6, the comparison between the groups was statistically significant at day $1(p<0.005)$ and day $3(p=0.001)$. A trend toward significance was highlighted at day $0(p=0,0510)$. At day 7 the scores were not statistically significant $(p=0.125)$.

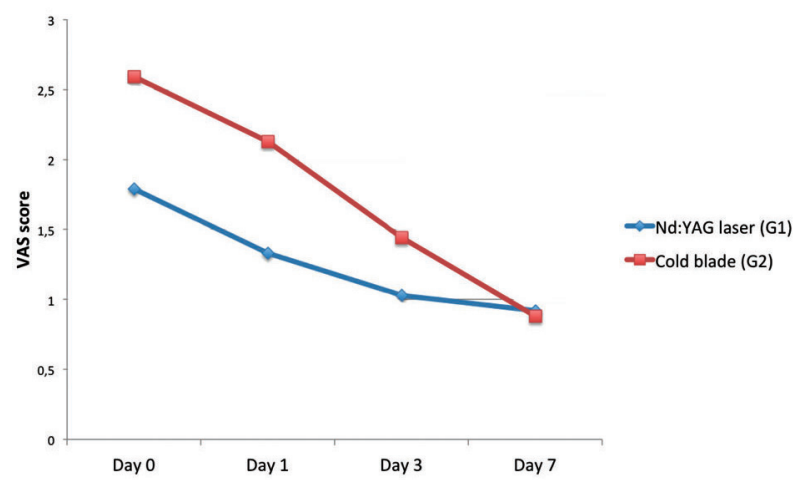

Figure 3. Comparison mean VAS scores at day 0, 1, 3 and 7 between the two groups. Lower VAS score was seen in G1 compared to G2 in day 0,1 , dan 3 , before showing the same score on day 7

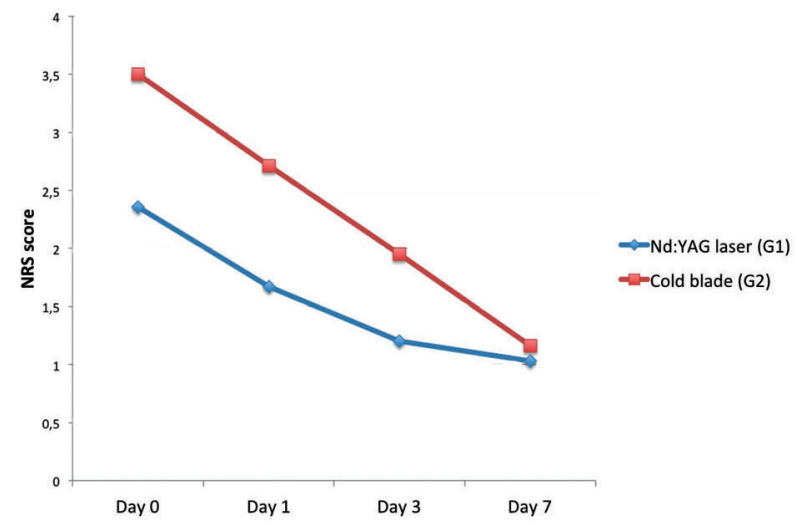

Figure 4. Mean NRS scores at day 0, 1, 3 and 7 between the two groups. Lower NRS score was seen in G1 compared to $\mathrm{G} 2$ in day 0,1 , and 3 , before showing relatively the same score on day 7

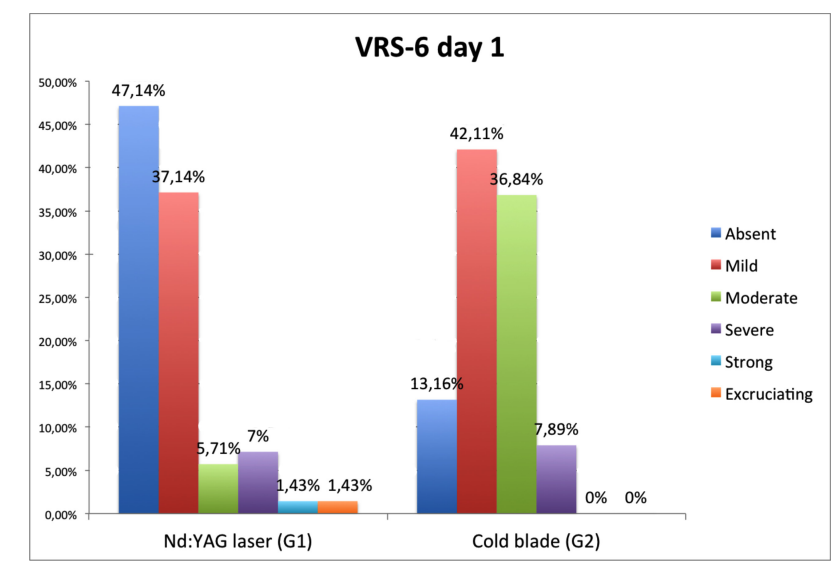

Figure 5. Mean VRS-6 scores at day 1 after surgery related to the two groups. VRS-6 scores in G1 were statistically lower than scores in $\mathrm{G} 2(p<0.001)$ 


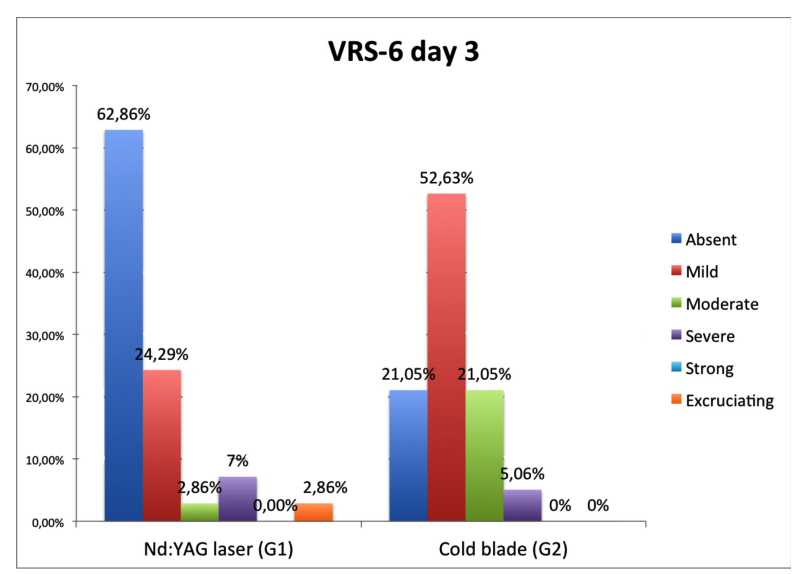

Figure 6. Mean VRS-6 scores at day 3 after surgery related to the two groups. VRS-6 scores in G1 were statistically lower than scores in $\mathrm{G} 2(p<0.001)$

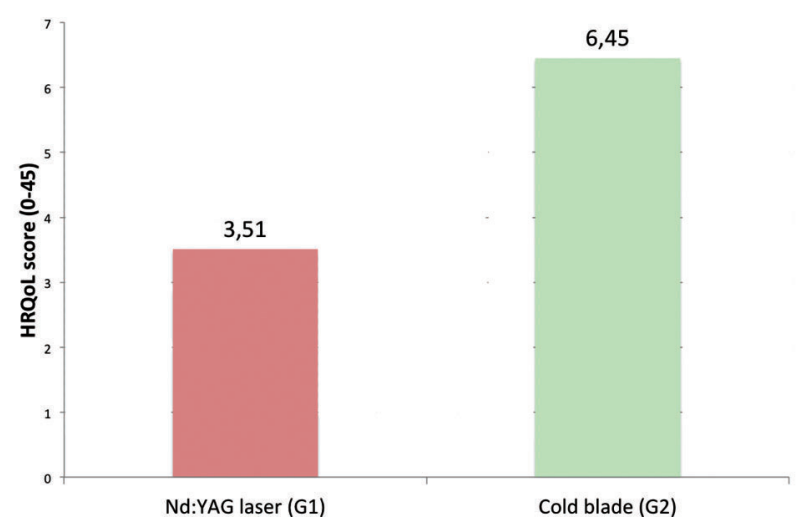

Figure 7. HRQoL scores related to three groups. HRQoL scores in G1 were statistically lower than scores in G2 $(p=0.0092)$

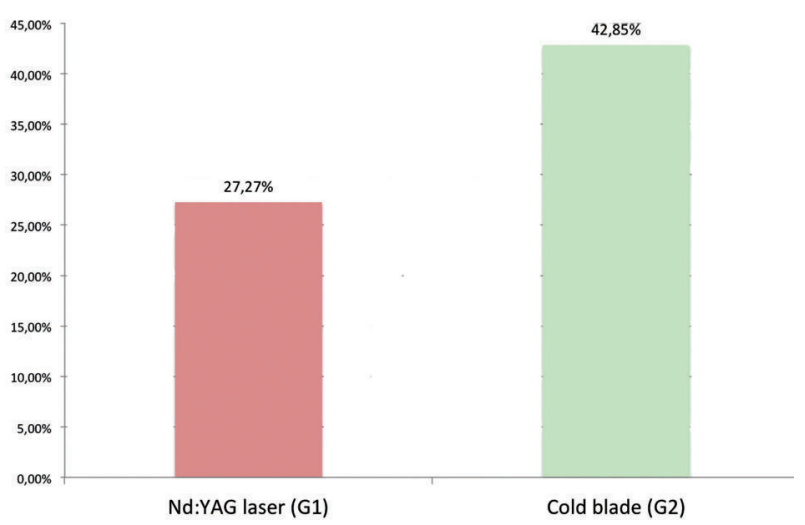

Figure 8. Use of analgesics in the two groups. More subjects in $\mathrm{G} 2$ need analgesics compared to G1 but not statistically significant.
As shown in Figures 5 and 6, at day 1 and 3 the VRS6 score in G1 was statistically lower (Bonferroni; $p<0.0001)$ than that in G2. Particularly, at day 1 after surgery $47.14 \%$ of patients in G1 and $13.16 \%$ of patients in G2 did not refer pain. At day 3 after surgery $62.86 \%$ of patients in $\mathrm{G} 1$ and $21.05 \%$ of patients in G2 did not experience pain. The HRQoL scores were analysed through Kruskal-Wallis test and they resulted significant $(p=0,0092)$ with the following mean scores: $3.51 \pm 5.03$ in G1 and $6.45 \pm 6.39$ in G2. The HRQoL scores were statistically lower in G1 than in $\mathrm{G} 2(p=0,0044)$ (Figure 7). Differences in the use of painkillers were not statistically significant $(p=0.204)$ among the two groups. However, only $27.27 \%$ of patients in G1 and $42.85 \%$ of patients in G2, need painkillers (Figure 8).

\section{DISCUSSION}

Few Authors described the potential advantages of $\mathrm{Nd}: Y A G$ laser in the post-operative course after oral soft tissues surgical interventions. ${ }^{5-8}$ Lopez-Jornet et al. compared the swelling and post-operative pain following surgical removal of oral leukoplakia performed through $\mathrm{CO}_{2}$ laser (Lasersat 20W, Satelec ${ }^{\circledR}$, Pierre Rolland, Barcelona, Spain) and cold blade. ${ }^{5}$ In the group of patients treated with cold blade the wounds were closed with $3 / 0$ sutures while in the laser-group, wounds were left unsutured. The Authors evaluated the swelling and the post-operative pain using a $10 \mathrm{~cm}$ visual analogue scale at 12 and 24 hours after surgery and every day for the following 6 days. Statistical evaluation revealed significant reduction of pain and swelling in the group of patients treated with laser during the first 3 days ( $p$-value at 12h, 1, 2 and 3 days after the surgery $\leq 0.05) .{ }^{5}$

Vivek et al. evaluated the usefulness of the Nd:YAG laser (Dornier Medilas Fibertom 4060, Dornier, Germany - fibre diameter: $400 \mu \mathrm{m}$; power: $15 \mathrm{~W}$ ) in a group of 28 patients treated for oral leukoplakia in terms of postoperative complications and the prognosis during three-years follow-up. ${ }^{6}$ Post-operative pain was assessed on a 10 -point scale $(0=$ no pain and $10=$ severe pain) at 72 hours after surgery and weekly for 5 weeks. Most of the patients reported a mild or moderate pain and a mild swelling around the intervention area with a slight limitation in the opening of the mouth. Such symptoms reached their peak at 72 hours after surgery and disappeared within one week. The complete healing of the wound occurred in a maximum of 5 weeks in 26 out of 28 patients, leading to a 6-month healing rate of $92,86 \%{ }^{6}$

Garcia et al. compared the excision of 68 mucoceles; sub-classified as follows: 38 excised through cold blade and 30 through $\mathrm{CO}_{2}$ laser (Lasersat 20W, Sharplan 1020, 
Tel Aviv, Israel) and evaluated the rate of complications and recurrence after surgery. ${ }^{7}$ Their data showed that laser treatment has more advantages compared with the traditional technique. Particularly, 5 recurrences were observed among cases treated with the traditional blade and only one in the group of mucoceles treated through laser. With regard to the post-operative discomfort the Authors found that patients treated with laser had only minimal postoperative pain and swelling and that no medications were needed. On the other hand, patients treated with cold blade, needed painkillers in over half of all the cases. ${ }^{7}$

Júnior et al. compared 18 labial frenectomies performed with conventional surgery and 22 with $\mathrm{Nd}$ :YAG laser (Fotona Fidelis Plus ${ }^{\circledR}$; energy: $40 \mathrm{~J}$; frequency: 40 $\mathrm{Hz}$; power: 4W) in terms of pain and functional consequences. $^{8}$ The post-operative data were recorded at 3 hours and 3, 7, and 15 days after surgery. Pain, analgesic consumption and discomfort during speech or chewing were assessed during consultation. A Visual Numeric Scale (VNS) was used to assess pain and discomfort related to oral functions, graded from left to right with values ranging from 0 (absence of pain and no functional complaints) to 10 (unbearable pain and severely compromised oral functions). No statistically significant postoperative differences were observed in the two groups. However, there was a variation in the pain and speech patterns on the third day, with lasertreated patients presented more complaints. ${ }^{8}$ In contrast to these results some studies found that in cases of labial frenectomy with different lasers (Nd:YAG, $\mathrm{CO}_{2}$, and Er,Cr:YSGG) most of the patients had no pain and no need for analgesics during the postoperative period. ${ }^{11,12}$

Analysis of data of our comparative study revealed that Nd:YAG laser is able to reduce both the pain and the post-operative discomfort. This may depend of the well-known analgesic effect of laser. ${ }^{3,4}$ Pogerl et al. hypothesized that the laser may have a "sealing" action on the vascular and lymphatic system. It prevents the leakage of fluids and inflammatory mediators reducing the intensity of the inflammatory reaction and the associated pain. ${ }^{13}$

Reducing of post-operative pain may depend on the bio-modulation on tissues surrounding the area of intervention. The bio-modulation of tissues is a secondary effect of the laser light that acts with a minor power on the areas near to the surgical field. It consists of different effects, particularly anti-inflammatory, bio-stimulation, anti-bacterial and analgesic. The anti-inflammatory effect occurs for an increase of the microcirculation, for a reduction of edema and for the suppression of the production by fibroblast of prostaglandins, interleukin-1 (IL-1) and tumour necrosis factor-alpha (TNF $\alpha) \cdot{ }^{13,14}$ The bio-stimulating effect acts on the immune system and on the collagen tissue, increasing the proliferation and the activity of fibroblasts, on the epithelial tissue increasing the turnover, on bone increasing the proliferation and activity of osteoblasts and the amounts of calcium and alkaline phosphatase..$^{15,16}$

The anti-bacterial effect has been demonstrated against some microorganisms such as Escherichia coli, Staphylococcus aureus, Actinomyces naeslundii and israelii, Pseudomonas aeruginosa, Enterococcus faecalis, and Streptococcus anginosus. ${ }^{2}$ Laser beam caused a decrease in the number of bacteria in different models. ${ }^{17,18}$ This could reduce the inflammation and infection in the tissues surrounding the area of intervention, further reducing pain and discomfort. The analgesic effect is achieved through two mechanisms: one indirect associated to the anti-inflammatory effects, and one direct against the nervous system. Particularly, the laser causes a hyperpolarization of the axonal membrane blocking the passage of the nervous impulse. It was also demonstrated that the bio-stimulation induces the production of endorphins, increasing the threshold level for pain with an oppioid-like effect. ${ }^{19,20}$

\section{CONCLUSION}

The use of Nd:YAG laser provides advantages for patients in terms of reduction of post-operative pain and discomfort.

\section{Conflict of interest}

No conflicts of interest can be disclosed by all of the Authors.

\section{REFERENCES}

1. Vescovi P, Merigo E, Fornaini C, Rocca JP, Nammour S. Thermal increase in the oral mucosa and in the jawbone during Nd:YAG laser applications: Ex vivo study. Med Oral Patol Oral Cir Bucal. 2012;17:e697-704.

2. Vescovi P, Conti S, Merigo E, Ciociola T, Polonelli L, et al. In vitro bactericidal effect of Nd:YAG laser on Actinomyces israelii. Lasers Med Sci. 2013;28:1131-5.

3. Scoletta M, Arduino PG, Reggio L, et al. Effect of low-level laser irradiation on bisphosphonateinduced osteonecrosis of the jaws: preliminary results of a prospective study. Photomed Laser Surg. 2010;28:179-84.

4. Vescovi P, Merigo E, Manfredi M, Meleti M, Fornaini C, Bonanini M, Rocca JP, Nammour S. $\mathrm{Nd}$ :YAG laser biostimulation in the treatment of bisphosphonate-associated osteonecrosis of the jaw: clinical experience in 28 cases. Photomed Laser Surg. 2008;26:37-46.

5. Lopez-Jornet P, Camacho-Alonso F. Comparison of pain and swelling after removal of oral leukoplakia with $\mathrm{CO}_{2}$ laser and cold knife: A randomized clinical trial. Med Oral Patol Oral Cir Bucal. 2013;18:e38-44. 
6. Vivek V, Jayasree RS, Balan A, Sreelatha KT, Gupta AK. Three-year follow-up of oral leukoplakia after neodymium:yttrium aluminum garnet (Nd:YAG) laser surgery. Lasers Med Sci. 2008;23:375-9.

7. Yagüe-García J, España-Tost AJ, Berini-Aytés L, Gay-Escoda C. Treatment of oral mucocele-scalpel versus $\mathrm{CO}_{2}$ laser. Med Oral Patol Oral Cir Bucal. 2009;14:e469-74.

8. Júnior RM, Gueiros LA, Silva IH, de Albuquerque Carvalho A, et al. Labial frenectomy with Nd:YAG laser and conventional surgery: a comparative study. Lasers Med Sci. 2013; Oct 22 [Epub ahead of print].

9. Hjermstad MJ, Fayers PM, Haugen DF. Studies comparing Numerical Rating Scales, Verbal Rating Scales, and Visual Analogue Scales for assessment of pain intensity in adults: A systematic literature review. J Pain Symptom Manage. 2011;41:1073-93.

10. Majid OW. Submucosal dexamethasone injection improves quality of life measures after third molar surgery: a comparative study. J Oral Maxillofac Surg. 2011;69:2289-97.

11. Pié-Sánchez J, España-Tost AJ, Arnabat-Dominguez J, Gay-Escoda C. Comparative study of upper lip frenectomy with the $\mathrm{CO}_{2}$ laser versus the Er, Cr:YAG laser. Med Oral Patol Oral Cir Bucal. 2012;17:e228-32.

12. Kara C. Evaluation of the patient perceptions of frenectomy: a comparison of $\mathrm{Nd}$ :YAG laser and conventional techniques. Photomed Laser Surg. 2008;26:147-52.

13. Pogrel MA, Yen CK, Hansen LS. A comparison of car- bon dioxide laser, liquid nitrogen cryosurgery, and scalpel wounds in healing. Oral Surg Oral Med Oral Pathol. 1990;69:269-73.

14. Huang TH, Lu YC, Kao CT. Low-level diode laser therapy reduces lipopolysaccharide (LPS) induced bone cell inflammation. Lasers Med Sci. 2012;27:621-7.

15. Basso FG, Pansani TN, Turrioni AP, Bagnato VS, Hebling J, et al. In vitro wound healing improvement by low-level laser therapy application in cultured gingival fibroblasts. Int J Dent. 2012;2012:719452.

16. Pyo SJ, Song WW, Kim IR, Park BS, Kim CH, et al. Low-level laser therapy induces the expressions of BMP- 2, osteocalcin, and TGF- $\beta 1$ in hypoxiccultured human osteoblasts. Lasers Med Sci. 2013;28:543-50.

17. Gutknecht N, Moritz A, Conrads G, Sievert T, Lampert F. Bactericidal effect of the Nd:YAG laser in in vitro root canals. J Clin Laser Med Surg. 1996;14:77-80.

18. Klinke T, Klimm W, Gutknecht N. Antibacterial effects of $\mathrm{Nd}$ :YAG laser irradiation within root canal dentin. J Clin Laser Med Surg. 1997;15:29-31.

19. Ferreira DM, Zângaro RA, Villaverde AB, Cury Y, Frigo L, et al. Analgesic effect of He-Ne (632.8nm) low level laser therapy on acute inflammatory pain. Photomed Laser Surg. 2005; 23:177-81.

20. Romeo U, Galanakis A, Marias C, Vecchio AD, Tenore $\mathrm{G}$, et al. Observation of pain control in patients with bisphosphonate-induced osteonecrosis using low level laser therapy: preliminary results. Photomed Laser Surg. 2011;29:447-52. 